\title{
Zika Virus Infection
}

National Cancer Institute

\section{Source}

National Cancer Institute. Zika Virus Infection. NCI Thesaurus. Code C128423.

An infection that is caused by the Zika virus, which is primarily transmitted via

mosquitoes; it is characterized by fever, skin rash, arthralgia, and conjunctivitis. 